Ltd., and produced by Mr. Harold Lowenstein with the co-operation of Sir Arthur Hill and his staff, gives a 'cross-section' of the activities of Kew as a public garden and as the centre of economic botany and horticulture in the Empire. The opening views give a picture of the Gardens as seen by the ordinary visitor, followed by sequences showing some of the work that goes on behind the scenes, both out of doors and under glass, in order to keep the Gardens in good condition and to provide a constant succession of bloom throughout the year. The most interesting section of the film from the scientific point of view is that illustrating the work that is carried out in the Herbarium, Jodrell Laboratory and Museums. The process of drying, pressing, mounting and storing botanical specimens is shown in the film in detail, and the method of examining and describing new species is also dealt with. The work of the Jodrell Laboratory consists largely of identifying fragments of plants (roots, stems, leaves, etc.) by microscopical examination, and one of the best sequences in the film illustrates the technique of examining a portion of stalk found in the stomach of a poisoned cow. The film ends with an impressionistic treatment of the part that Kew has played in the foundation and improvement of many of the important agricultural enterprises throughout the Empire. The introduction of Para rubber and cinchona (quinine) from South America via Kew to the East in the middle of last century is illustrated, and more recent instances show that this type of work is still being undertaken. This film will undoubtedly be of value in spreading a knowledge of the great importance of the Royal Botanic Gardens in the botanical and horticultural work of the Empire, and it is hoped that it will obtain a wide circulation, especially among schools and other educational institutions.

\section{Palestine Folk Museum}

As appeal for financial assistance towards the needs of the Palestine Folk Museum, appearing in The Times of April 19, should meet with a sympathetic reception from the widespread public in Great Britain and America, which is interested in the history and culture of Bible lands. The museum, which is situated in Jerusalem, was opened in 1936 under a committee formed in the preceding year and composed of representatives of the resident English, Arab and Jewish communities. Unfortunately it has no funds, and its work is carried on by voluntary helpers-no inconsiderable burden, even with a tolerant standard of efficiency. No Government grant has been made towards the expenses of the Museum, nor is it eligible to receive assistance from the funds provided by the Carnegie Corporation to aid the museums of the Empire through the Museums Association, Palestine being a mandated territory. Until something in the nature of an assured income is provided, it will not be possible to appoint a curator, an obvious necessity, or to carry on research. Folk museums now have a recognized and an increasingly important part to play in the record and study of cultural history; but the value to the student, whether archæologist or historian, of a folk museum in a country in the near East, such as Palestine, is exceptional. A prolonged period of little cultural change has preserved peasant arts and industries, with their characteristic implements and appliances, domestic and other, virtually unchanged for many centuries, so that objects can be seen in daily use in the villages, which are identical in form and purpose with finds from Palestinian sites of the Bronze and Iron Ages. This period of comparative immobility is rapidly drawing to a close under the impact of an expansion of population and industry under Western influence.

\section{Science and the Conservation of Food}

IN his Friday evening discourse at the Royal Institution on April 16, Mr. T. Macara described some special problems of "Science and the Conservation of Food". While the term 'conservation of food' may be applied to many aspects of the production and handling of foods, he confined himself to problems connected with some common types of manufactured food. The first problems discussed were mould growth and fermentation, crystallization, and absence of jelly property in jam. As regards mould growth and fermentation, Mr. Macara put forward the theory that their prevention depends on the production of a jam having a higher osmotic pressure than that of mould spores or yeast cells, and he showed how this result could be achieved. The jelly property of jams is due to the fruit pectin, and it was shown how the jellifying property of this pectin may be lost or destroyed through lack of knowledge of its properties. Problems connected with the preservation of fruits, vegetables and meat products were then discussed. The British Food Manufacturers' Research Association has found certain bacteria the spores of which show an extraordinary high resistance to heat. Boiling for 8 hours or heating to $230^{\circ} \mathrm{F}$. for an hour fails to destroy them. It was pointed out that these times apply to small quantities of materials, and that when larger quantities have to be sterilized it is necessary to know the rate at which heat penetrates the product. The question of food storage in cans is surrounded with difficulties on account of defects in the coating of tin on the cans. A number of cases have been met with where the cans became perforated after three or four months' storage.

\section{Joint Committee on Materials and their Testing}

A Commitree having the above title has now been set up by leading technical institutions and societies in Great Britain to act as the British national organization in matters relating to materials and their testing. The need in Great Britain of some means to provide for more adequate co-ordination of the study of materials and their testing has, during the past year, received the earnest consideration of the principal technical institutions and societies which are concerned directly and indirectly with these important subjects. Twenty-two institutions and societies are represented on the Joint 
Committee. Essentially, the work of the Joint Committee will be divided into two fields of activity, national and international, of which the former will no doubt be of major importance. As a commencement in this field, the Committee is now engaged in making arrangements for a general discussion on the subject of the notched bar test to be held in Manchester in the early autumn of the present year. The activities of the International Association for Testing Materials in Great Britain are at present entrusted to the keeping of a British Committee, and the latter has agreed that, at the conclusion of the London Congress of the International Association for Testing Materials now being held (April 19-24), the Joint Committee shall take over the representation in Great Britain of all matters connected with the International Association. The first chairman of the Committee is Dr. H. J. Gough, largely through whose initiative the Joint Committee has come into being; the secretary is Mr. C. W. J. Taffs, of the staff of the Institution of Mechanical Engineers, the Council of which has kindly offered the necessary facilities for office work at Storey's Gate, St. James's Park, London, S.W.1.

\section{New Commonwealth Society}

THE fourth annual report of the New Commonwealth Society and Institute for the year ended September 30, 1936, refers to the way in which the events of the year have emphasized the soundness of the thesis of an equity tribunal and an international police force which the Society was created to advocate, and the report indicates that the New Commonwealth Society is rapidly gaining ground. Forty-four countries are now represented in the membership, which including the international members shows an effective increase of 252 on the year. The position of the group associate membership is less satisfactory. In addition to the publication of the journal and numerous pamphlets during the year, the British Section has initiated a scheme for a "Writers Panel" to develop publicity in the Press. Brief reviews of the activities of other national sections are included in the report. The section dealing with the New Commonwealth Institute outlines the progress of collective research on procedure for peaceful change, a basis for which has been provided by a report prepared by Prof. K. Strupp dealing with the possibility of an international peace convention and peace charter. A department for collective research on the organization of some form of international force has been initiated under Capt. E. Abraham, and similar activity has also been initiated on the reform of the League of Nations. Detailed proposals have already been forwarded to the members of the Advisory Research Committee and to the Foreign Offices of all States members of the League. A further development in the year is the organization of an information department.

\section{Additional Food for the Special Areas}

A MEMORANDUM on the Special Areas Bill dealing with the provision for additional food, etc., for mothers and children in distressed areas has been submitted to the Prime Minister by the Children's Minimum Council. The memorandum submits evidence of the inadequacy of incomes in distressed areas based, in respect of food, on figures given in "A Revised Estimate of the Poverty Line" by R. F. George (J. Roy. Statistical Soc.). The figures indicate broadly the increasing extent to which the incomes of the unemployed fall below the requirements for health as the size of the family increases. Other evidence of the lack of nourishment of mothers and children in these areas is presented, and the limitations of the present provision by local authorities in England and Wales in consequence of the inability of local rates to support it are also reviewed and discussed. The memorandum urges that the Government should provide in the fortheoming Bill for grants from the national exchequer to local authorities in the Special Areas to cover the whole cost of the supply of free milk to all children in public elementary schools and to scholarship children in secondary schools; the supply of free school meals to all children belonging to families where the amount available for food falls below a scale to be determined by the Ministry of Health; the supply of free boots to school children in such families; and the supply of free milk to expectant and nursing mothers and to children under school age in such families.

\section{Lancashire and Cheshire Fauna}

THe twenty-second report of the Lancashire and Cheshire Fauna Committee, just issued, which covers 1935 , is probably the most useful publication of the Committee apart from its Check List. It deals chiefly with vertebrates, and in addition to the records of the occurrence of rare species, includes detailed tables of the distribution of the woodcock, grey squirrel and great crested grebe in Cheshire, and the pochard, great spotted woodpecker and redstart in both counties. The committee which announces it is also to include the recording of the marine fauna within the three mile-limit in its work, makes an addition of 101 species new to both counties and 25 new to one county, the former consisting of 28 Coleoptera, 20 Diptera, 20 Hymenoptera, 12 sawflies, 8 Acari, 5 Hemiptera, 2 Mallophaga and Neuroptera and I each of Mollusca, Lepidoptera, Anoplura and Siphonaptera. The more interesting specific records are: a new colony of Natterjack toads at Storeton, Cheshire; a November golden oriole at Macclesfield; numerous reports of the invasion of crossbills ; a meadow-pipit at Heywood, Lancashire, with an abnormal clutch of five sky blue eggs spotted with red, and a magpie that has developed the habit of nesting on the ledge of a steep moorland cliff there ; a chiffchaff wintering there, although it does not nest in the district; a December immigration of blackbirds ; an investigation of swallow broods showing that 35 broods in Lancashire averaged 4.05 young and 97 broods in Cheshire averaged 4 young; a kestrel taken in Manchester and found to have its plumage and its nostrils so heavily laden with soot that none of the usual parasites inhabited it. 